\title{
The Impact of Leadership Styles on the Job Satisfaction of Employees in a Garment Factory of Sri Lanka
}

Dr. M. A. Shantha Wijesinghe

Department of Geography, University of Sri Jayewardenepura, Sri Lanka

Corresponding Author: Dr. M. A. Shantha Wijesinghe „, E-mail: shanthawi@sjp.ac.lk

\section{ARTICLE INFORMATION}

Received: December 02, 2020

Accepted: January 04, 2021

Volume: 3

Issue: 1

DOI: $10.32996 /$ jhsss.2021.3.1.8

\section{KEYWORDS}

Autocratic, Democratic and Transactional Leadership Styles, Job satisfaction

\section{ABSTRACT}

Job satisfaction is a common but important theme discussed at organizational level. It refers to the attitude and feelings that the people have about their work. Main concern of every organization is to maintain the satisfaction of the employees so that the organizational goals can be achieved successfully. Job satisfaction of the employees can be determined by many factors. Among them, leadership style followed by the leaders is also one of the important factors. Leadership style is the manner and approach of providing direction, implementing plans and motivating people.Many scholars have addressed the impact of leadership styles on the job satisfaction of employees in different manner. But, literature on this topic in the context of Sri Lanka has not sufficiently developed. There are only few studies covered the subject of leadership in Sri Lanka particularly limiting to few sectors. Therefore, this study attempts to fill that gap of the knowledge by addressing how leadership styles affect job satisfaction of the employees, particularly in a garment factory in Sri Lanka. Methodologically, deductive testing theory approach was followed by this study. Theory was developed by the literature based on the pilot study. As the pilot study confirmed that three major leadership styles such as democratic, autocratic and transactional style are followed by the leaders, the impact of these three styles on the job satisfaction of employees were examined by giving a questionnaire to a stratified random sample of 60 employees. Basic hypothesis of the study was that the transactional leadership style should be the most significant in determining the job satisfaction according to human nature. But the outcome of this study confirmed that the impact of democratic style was statistically more significant than autocratic and transactional styles by rejecting the initial hypothesis.

\section{Introduction}

Job satisfaction is a common but important theme discussed at organizational level. Main concern of every organization is to maintain the satisfaction of the employees so that the organizational goals can be achieved successfully. Job satisfaction is defined by different authors in different manner and there is no general agreement of defining it. Historically, Happock (1935) has defined job satisfaction as any combination of psychological, physiological and environmental circumstances that cause a person truthfully to say I am satisfied with my job. This definition mainly emphasizes something internal that has to do with the way how the employees feel. In defining job satisfaction, Vroom (1964) has focused on the role of the employees in the workplace. Vroom (1964) defines job satisfaction as affective orientations on the part of individuals towards work roles which they are presently occupying.

According to Armstrong (2006), the term job satisfaction refers to the attitude and feelings that the people have about their work. As emphasized by Armstrong, positive and favourable attitudes towards the job satisfaction indicate job satisfaction and negative and unfaourable attitudes towards the job indicate job dissatisfaction. George and Jones (2008) define job satisfaction as the collection of feelings and beliefs that people have about their current job. In addition to the attitudes about their jobs as a

K C AL-KINDI CENTER R D FOR RESEARCH AND EVELOPMENT Your gateway to world-class research

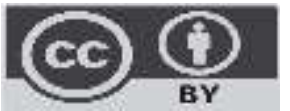

Published by Al-Kindi Center for Research and Development. Copyright (c) the author(s). This open access article is distributed under a Creative Commons Attribution (CC-BY) 4.0 license 
whole, people can also have attitudes about various aspects about their jobs such as the kind of work they do, their coworkers, supervisors or subordinates and their pay (George and Jones, 2008).

Job satisfaction of the employees in any organization can be determined by many factors such as the nature of work they do, benefits, facilities provided. Among such factors, leadership style followed by different leaders is also one of the important factors determining the level of job satisfaction of the employees. Leadership style is the manner and approach of providing direction, implementing plans and motivating people. As seen by the employees, it includes the total pattern of explicit and implicit actions performed by their leader (Newstrom and Davis, 1993). According to Flynn (2009) leadership style is the adaptation of varying techniques used by leaders to provide guidance and influence participation of subordinates in a specified course to be navigated. Particularly, the manner of providing direction and motivating people by a leader directly affects the job satisfaction of employees in any organization.

Many scholars have done the research about the impact of leadership styles on job satisfaction of the employees. Mester et. al., (2003) have confirmed that the role of a leader has a direct influence on job satisfaction among followers. Madlock (2008) has also explained that the employees are most satisfied when they perceive their leaders to possess a combination of rational and task oriented behaviours. Berson and Linton (2005) have confirmed that there is a positive relationship between transformational leadership and job satisfaction. As emphasized by Madlock (2008), effective and clear communication of vision and goals results in acceptance and higher satisfaction levels among followers.

Even though many scholars have addressed the impact of leadership styles on the job satisfaction of employees in different manner, literature on this topic in the context of Sri Lanka has not sufficiently developed. There are only few studies covered the subject of leadership in Sri Lanka, particularly limiting to few sectors (Raveendran and Gamage, 2018). As cited by Raveendran and Gamage (2018), they are the studies such as the impact of transformational and transactional leadership styles on various outcomes like knowledge creation in Sri Lankan Software Industry (Athukorala, Perera and Meedeniya, 2016), employee performance in banking industry (Chamika and Gunasekara, 2016) and union and organizational commitment in public sector organizations in Sri Lanka (Dhammika, Ahmed and Sam, 2013). Therefore, this study attempts to fill that gap of the knowledge by addressing how leadership styles affect job satisfaction of the employees, particularly in a garment factory in Sri Lanka.

Selection of this problem relating to particular garment factory can be justified by the high turnover rates experienced by the factory. In the last three years of 2017, 2018 and 2019, it has been experiencing a serious issue of employee turnover reporting the turnover rates as 10.5, 13.3 and 16.2 per cent respectively. All these rates are above the average expected rate of 3.5 per cent by the factory. Apart from that, data relating to the target achievement have also confirmed that monthly targets of production lines are always below the expected levels reporting nearly $15 \%$ gap between expected and perceived targets. It was also obvious that the target achievements significantly vary among production lines. In examining why, it experienced so, pilot study conducted through informal discussions confirmed that the leadership styles particularly followed by the line managers in this factory seem to be the reason behind the issue.

Therefore, this paper attempts to achieve the following specific objectives;

- To identify the leadership style mainly followed by different leaders working in different lines of the selected garment factory.

- To examine whether job satisfaction of the employees significantly varies according to different leadership styles.

- To assess the impact of each style on the job satisfaction of employees.

\section{Literature review}

Job satisfaction has been defined by many scholars in different manner. Poon (2003) defines it as a positive psychological state that emerges when individuals evaluate their work and work experience. Hoppock (1935) defines it as a theoretical construct related to mental, psychological and environmental situations that prompts to a person to express fulfilment with their occupation. As explained in the introduction, job satisfaction has been operationalized in this paper according to the definitions of George and Jones (2008) and Armstrong (2006) that emphasize attitudes and feeling about work.

Job satisfaction is determined by various factors such as monetary and non-monetary benefits, performance evaluation and appraisal, career path development, employer-employee relationships etc. Among them leadership style followed by the leaders is also one of the important factors determining job satisfaction. According to Northouse (2007), leadership is a process through which an individual influences a group of people to attain common goals. Aligning with the leadership, leadership style is the manner and approach of providing direction, implementing plans and motivating people. According to such manners and approaches, leadership styles followed by different leaders are identified. In literature, different types of leadership styles have been discussed. Among them, the styles such as democratic, autocratic, bureaucratic, laissez faire, transactional and 
transformational styles have been significantly addressed, as such styles are commonly followed by the leaders in directing and motivating employees. Thus, in this paper as well, three main leadership styles such as democratic, autocratic and transactional styles were examined, as the pilot study confirmed that the line managers, as the leaders of this garment factory, mainly follow these styles in directing the people to work.

\subsection{Democratic leadership}

Anderson (1959) defines democratic leader as the person who encourages participation in decision making, offers guidance to group members, participates in the group and allows inputs from subordinates. As emphasized by Gastil (1994), democratic leadership style is identified in terms of the performance of three functions such as distributing responsibility among the membership, empowering group members and aiding the group's decision-making process. Democratic leaders are thoughtful and share responsibility with their subordinates. They allow subordinates to develop their own leadership skills. As pointed out by Bass (2008), democratic leaders are independent, reducing the stress of the leaders. Such leaders involve subordinates in decision making even though the final decision is processed. Democratic leader always consults his followers for decision making. He has less control over their subordinates compared to other leadership styles. Such a leader works well among the subordinates who possess an adequate knowledge, when the group work performs well with good understanding (Giltinane, 2013).

\subsection{Autocratic leadership}

Autocratic leadership style is defined as the style with sole decision making and command with power in single dominant leader (De Hoogh et.al., 2015). Autocratic leaders would prefer to establish strict regulations, control processes and remain in formal and professional relationship with their subordinates (Malos, 2012). According to Sauer (2011), this style does not instill learning mentality which is crucial to stimulate proactive attitudes among employees. However, Sauer further emphasizes that autocratic leaders give their subordinates clear and short instructions on what to do and how to do it and it helps to perform tasks effectively, solve identified problems and meet targets or deadlines when the time is a critical factor. As pointed out by Gill (2014) within the autocratic style, one person entails of making all strategic decision for his or her subordinates. Within this style, members are not allowed to give in their decisions and the leader does not consult the members before taking decisions (Vugt et.al., 2004). Gill (2014) emphasizes that autocratic leaders are best for newly formed businesses as the subordinates have to be guided to improve the efficiency within the organization.

\subsection{Transactional leadership}

Transactional leadership style is the style of leadership in which the leader promotes compliance of his or her followers through both rewards and punishments (James and Ogbonna, 2013). Transaction means exchange and transactional leadership deals with the exchange between the leader and his subordinate. According to Naidu and Van (2005), it is a leader-follower exchange based leadership in which leader exchanges rewards or punishments with the follower for the task performed, and in return expects productivity, efforts and loyalty from the followers. The basis of transactional leadership is a transaction or exchange process between leaders and followers. Transactional leader recognizes followers' needs and desires and then clarifies how those needs and desires will be satisfied in exchange for meeting specified objectives or promoting certain duties. Thus, the followers receive rewards for job performance whereas leaders benefit from the completion of tasks. They have highlighted three dimensions of transactional leadership. They are the contingent rewards, active management by exception and the passive management by exception. Contingent rewards link the goals to rewards, clarify expectations and provide necessary resources for successful performance. Active management by exception is where transactional leader actively observes the work of their subordinates and looks out for deviations from standards and rules. Passive management by exception is where transactional leader waits till the problems and issues arise to take actions to sort them (James and Ogbonna, 2013).

\section{Methodology}

Research design of the study is the testing theory method emphasized by the deductive approach. The theory was developed in terms of the literature relating to job satisfaction and leadership styles. As the pilot study confirmed that three major leadership styles such as democratic, autocratic and transactional style are followed by the line managers, as leaders in this garment factory, initially the impact of these three styles on the job satisfaction of employees were examined. Accordingly, the conceptual frame of this study can be highlighted by the following diagram. 


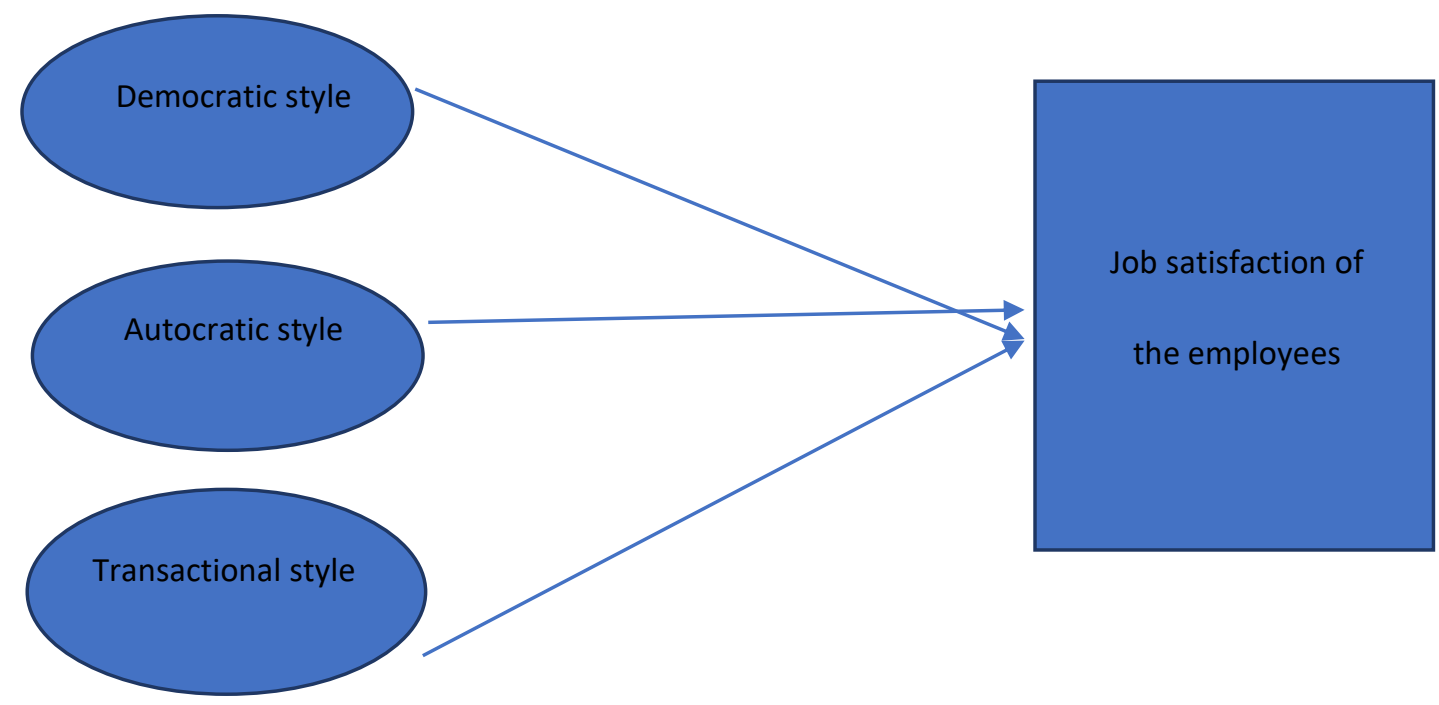

Figure 1: Conceptual frame of the study

Source: Author developed based on literature, 2020

As highlighted by the above diagram, if leadership styles do not make any impact on the job satisfaction of employees, whatever the style is followed, job satisfaction of the employees should be same while all other factors are constant. Accordingly, the factor controlling methodology was used in examining the impact of leadership styles on job satisfaction. The following null and alternative hypothesis were tested at 0.05 significant level by applying Analysis of Variance (ANOVA).

$\mathrm{H}_{0}$ - Null hypothesis: Job satisfaction of the employees does not vary according to leadership styles followed by the line managers.

$\mathrm{H}_{1}$ - Alternative hypothesis: Job satisfaction of the employees does vary according to leadership styles followed by the line managers.

Apart from the above main hypothesis, it was assumed that the transactional leadership style should be the most significant in determining the job satisfaction of employees according to human nature. For testing this matter, paired $t$ test was used at 0.05 significant level.

Operationalization of the above mentioned conceptual frame is summarized by the Table 1 .

\begin{tabular}{|c|c|c|}
\hline Variable & Dimension & Scale used \\
\hline Job satisfaction & $\begin{array}{l}\text { - Attitude about the pay (George and } \\
\text { Jones, 2008) } \\
\text { - Attitude about supervisors (George and } \\
\text { Jones, 2008) } \\
\text { - Feeling about the work (Armstrong, } \\
\text { 2006) }\end{array}$ & $\begin{array}{l}\text { Five point Likert scale from highly } \\
\text { agree to highly disagree }\end{array}$ \\
\hline Democratic style & $\begin{array}{l}\text { - } \quad \text { Distributing responsibility (Gastil, 1994) } \\
\text { - Empowering group members (Gastil, } \\
\text { 1994) } \\
\text { - Consult followers for decision making } \\
\text { (Giltinane, 2013) }\end{array}$ & Do \\
\hline Autocratic style & $\begin{array}{l}\text { - Sole decision making (De Hoogh et.al., } \\
\text { 2015) } \\
\text { - Command with power (De Hoogh et.al., }\end{array}$ & Do \\
\hline
\end{tabular}




\begin{tabular}{|l|l|l|}
\hline & $\begin{array}{l}2015) \\
\text { Does not consult the members before } \\
\text { taking decisions (Vugt et.al., 2004) }\end{array}$ & \\
\hline Transactional style & $\begin{array}{l}\text { Promote followers through rewards } \\
\text { (James and Ogbonna, 2013) }\end{array}$ & Do \\
\hline $\begin{array}{l}\text { Recognize followers' needs (James and } \\
\text { Ogbonna, 2013) }\end{array}$ & $\begin{array}{l}\text { Actively observe the work (James and } \\
\text { Ogbonna, 2013) }\end{array}$ & \\
\hline
\end{tabular}

Table 1: Operationalization of variables

Source: Author developed based on literature, 2020

Total population belonging to the selected three lines of this garment factory is 150 employees distributing as 50,40 and 60 among Line A, B and C respectively. A representative sample of 60 employees was selected for the study by following stratified random sampling technique. That is equal to $40 \%$ of the total population. Thus, the sample consists of 20,16 , and 24 employees representing Line $A, B$ and $C$ in turn.

As the data gathering instrument, questionnaire was used by setting the questions according to the dimensions highlighted in Table 1 with five point Likert scale. Ordinal Likert scale data was quantified by giving a numerical scale from 5 - 25 . Likert scale was set from highly disagree to highly agree by valuing the lowest for highly disagree and the highest for highly agree. For example, referring to the variable of job satisfaction higher the value indicates higher the job satisfaction while lower the value specifies lower level of job satisfaction. Similarly, higher the value reports for any leadership style confirms the practice of particular style while lower the value indicates the deviation from that particular style. For the analysis of data and for testing of hypothesis, mean, grand mean, standard deviation, paired $t$ test and the Analysis of Variance (ANOVA) were used.

\section{Results and Discussion}

\subsection{Leadership styles}

The first objective of this study is to identify the leadership style mainly followed by different leaders working in different lines of this garment industry. For this purpose, as highlighted in Table 1, three dimensions relating to each leadership style were examined. Accordingly, the Grand Mean (GM) values of three lines relating to each leadership style are presented by the Table 2.

\begin{tabular}{|l|c|c|c|}
\hline Leadership style & Line A & Line B & Line C \\
\hline GM of democratic style & 8.5 & 20.5 & 10.4 \\
\hline GM of autocratic style & 18.6 & 10.2 & 9.4 \\
\hline GM of transactional style & 9.6 & 10.6 & 19.5 \\
\hline
\end{tabular}

Table 2: Grand Mean (GM) values of leadership styles by lines

Source: Survey data, 2020

According to the data in Table 2, grand mean of the democratic style for the line A, B and C reports $8.5,20.5$ and 10.4 respectively. As explained in methodology, higher the value reports for any leadership style confirms the practice of that particular style. Thus, out of these three values, the highest score is reported by the Line B. Compared to other two grand means, it is so clear that 20.5 is a higher value scored by the Line B. Accordingly, it can be concluded that the line manager, as the leader in Line $B$, is more democratic. Similarly, the highest grand mean value (18.6) of autocratic style is reported by the Line A by confirming that the line manager of Line $A$ is more autocratic. As the highest grand mean value of transactional style is reported by the Line $\mathrm{C}$ compared to other two, it is evident to conclude that the line manager of Line $\mathrm{C}$ majorly follows the transactional style.

\subsection{The impact of leadership styles on the job satisfaction}

In order to assess the impact of leadership styles on job satisfaction, initially the job satisfaction of the employees of three lines was examined according to three dimensions such as attitudes about the pay, attitudes about the supervisor and feeling about the work as highlighted in Table 1 . Thus, the mean values of job satisfaction of the employees in Line A, B, and C with their relevant standard deviations are given by Table 3 . 


\begin{tabular}{|c|c|c|c|}
\hline Production Line & $\begin{array}{c}\text { Mean value of job } \\
\text { satisfaction }\end{array}$ & Standard deviation & $\begin{array}{c}\text { Main leadership style as confirmed } \\
\text { by the data Table 2 }\end{array}$ \\
\hline A & 8.7 & 1.40 & Autocratic \\
\hline B & 20.0 & 1.12 & Democratic \\
\hline C & 13.5 & 0.98 & Transactional \\
\hline
\end{tabular}

Table 3: Level of job satisfaction by lines

Source: Survey data, 2020

As per the data in Table 3, mean values of job satisfaction of the employees in Line A, B and C reported 8.7, 20.0 and 13.5 respectively. As their standard deviations are closer to zero it can be concluded that the level of job satisfaction of all employees in each line does not significantly vary from mean and almost all employees of each line have the same attitude about their job as represented by mean. Accordingly, from these values it is evident that there is a clear difference of the level of job satisfaction of the employees of these three lines and that difference clearly relates to leadership style majorly followed by the line managers of each line. For example, data in Table 3 confirms that the highest level of job satisfaction is reported by the Line $B$ in which the democratic leadership style is practiced and lower level of job satisfaction is reported by the Line A, from which autocratic style was reported.

However, these mean differences itself are not enough to statistically conclude whether leadership styles make a significant impact on the job satisfaction of the employees. Therefore, the Analysis of Variance (ANOVA) was used to test whether leadership styles significantly make an impact on the job satisfaction of the employees. For this purpose, level of job satisfaction of the employees was tabulated according to three leadership styles such as democratic, autocratic and transactional followed by Line B, Line A and Line C respectively. Thus, the ANOVA output relating to these three styles is presented by the Table 4 .

\begin{tabular}{|l|l|l|l|}
\hline Component & Sum of squares & Degrees of freedom & Variance estimate \\
\hline Total sum of squares & 1558.50 & $60-1=59$ & 26.42 \\
\hline $\begin{array}{l}\text { Between Sum of Squares } \\
\text { (BSS) }\end{array}$ & 1007.90 & $03-1=02$ & 503.95 \\
\hline Residuals & 550.60 & $60-3=57$ & 9.66 \\
\hline
\end{tabular}

Table 4: ANOVA output of the job satisfaction by leadership styles

Source: Based on field survey, 2020

Results of the ANOVA output in Table 3 clearly indicate that the explained variation (1007.9) is higher than the residual part (550.6) which is highlighted as the unexplained variation. As a result, F value reports 52.17 leading to high significance, as the $p$ value is 0.00 . Thus, there are sufficient evidence to reject the null hypothesis by concluding that the job satisfaction of the employees in Line A, B and C significantly varies according to these three leadership styles. It means that the leadership styles followed by the line managers of this garment factory significantly make an impact on the job satisfaction of employees.

Another assumption of this study is that the job satisfaction of the employees working under transactional style should be higher than that of the employees under democratic style because transactional style initially promotes the employees to work by rewards and benefits. According to the human nature, it was assumed that the employees are highly satisfied when they are rewarded. If so, the mean value of job satisfaction of the employees under transactional style should be higher than that of the employees under democratic style. But the mean value of the job satisfaction of the employees under transactional style reports only 13.5 while the relevant value of the employees under democratic style reports 20.0 by confirming that the job satisfaction of the employees under transactional style is lower than that of the employees under democratic style. In order to further test this hypothesis, paired $t$ test was run by setting the null hypothesis that the job satisfaction of the employees under transactional style is not higher than that of the employees under democratic style. According to the results of the paired $t$ test, reported $t$ value $(0.62)$ was not sufficient to reject the null hypothesis at 0.05 significant level. Thus, there are no sufficient evidence to conclude that the job satisfaction of the employees under transactional style is higher than that of the employees under democratic style.

\section{Conclusion}

According to the first specific objective of this study, it was found that the line managers of the selected three lines follow completely different three leadership styles in their production process. In examining the second specific objective, it was so clear that the job satisfaction of the employees significantly varies according to different leadership styles followed by the line managers. Particularly, the employees in Line B, are so satisfied regarding the attitudes and feeling about their work as emphasized by George and Jones (2008) and Armstrong (2006). Employees in Line C are moderately satisfied but those in Line A 
do not have positive attitudes and feeling about their work. Sometime the employees in Line A and C may be satisfied of their job regarding some other criteria but not in terms of the criteria highlighted by George, Jones and Armstrong.

However, the employees who are under the leadership of democratic style are the more satisfied employees compared to those under the styles of autocratic and transactional. Thus, the ANOVA confirmed that the leadership styles make a significant impact in determining the job satisfaction of employees. That was highly significant, as the null hypothesis was rejected at 0.00 significant level. As emphasized by Gastil (1994) and Giltinane (2013), leaders following democratic style particularly in Line B, have been more democratic by distributing responsibility, empowering group members and consulting followers for decision making. However, the impact of transactional leadership style is less compared to that of democratic style. As emphasized by James and Ogbonna (2013), transactional leader recognizes followers' needs and desires and then clarifies how those needs and desires will be satisfied in exchange for meeting specified objectives or promoting certain duties. Thus, the followers receive rewards for job performance whereas leaders benefit from the completion of tasks. However, this study confirmed that the rewards and recognition and the observation of work have not been important in satisfying the employees of this particular garment factory. Accordingly, it can be concluded that the human nature demanding more rewards and benefits has not been important in determining the job satisfaction of the employees even though James and Ogbonna 2013) emphasized so.

Employees in Line A are the highly dissatisfied employees under the leadership style of autocratic majorly. As emphasized by De Hoogh et.al. (2015) and Vugt et.al. (2004), autocratic leaders are the sole decision makers, commanding with power and they normally do not consult members before taking their decisions. Manner and the approach directing in this way normally does not lead to the satisfaction of employees. As emphasized by them, this study also confirmed that the autocratic leadership style is not practicable in directing people to attain the goals of production targets.

This study only focused three selected leadership styles determining the job satisfaction of employees in a garment factory. But, there are many more leadership styles determining job satisfaction. Particularly, in a garment factory environment, bureaucratic and transformational styles may also be followed. Sometime transformational style may be more practicable in achieving the targets, as the leaders play the role of change agent in such a style. Conducting research by selecting such styles is open to other researchers.

Funding: This research received no external funding.

Acknowledgement: Support given by the Mangers and the workers of the garment factory to complete this study successfully is highly acknowledged.

Conflicts of interest: The author declares no conflicts of interest.

\section{References}

[1] Anderson, R. C. (1959). Learning in discussions: A resume of the authoritarian-democratic studies. Harvard Educational Review, $29,201-212$.

[2] Armstrong, M. (2006). A Handbook of Human Resource Management Practice. $10^{\text {th }}$ Ed. Kogan Page Publishing.

[3] Bass, B. M. (2008). Leadership and performance beyond expectations. Free Press. 3 - 242.

[4] Berson, Y. and Linton, D. (2005). An examination of the relationships between leadership style, quality and employee satisfaction in R\&D versus administrative environments. R\&D Management, 35(1),51-60.

[5] De Hoogh, H. B., Greer, L. L. and Hartog, D. N. D. (2015). Diabolical dictators or capable commanders? An investigation of the differential effects of autocratic leadership on team performance. The Leadership Quarterly. 26 (05)

[6] Flynn, S. I. (2009). Transformational and Transactional Leadership. Research Starters Sociology. 1 - 6.

[7] Gastil, J. (1994). A definition and illustration of democratic leadership. Available from https://journals.sagepub.com/doi/10.1177/001872679404700805. Accessed on 23.05. 2020.

[8] George, J. M. and Jones, G. R. (2008). Understanding and Managing Organizational Behaviour. $5^{\text {th }}$ ed. Pearson.

[9] Gill, R. (2014). Spirituality at work and the leadership challenge. Journal for the Study of Spirituality, 4(2), 136 - 148.

[10] Giltinane, C. L. (2013). Leadership styles and theories. Nursing Standard, 27(41), $09-35$.

[11] Happock, R. (1935). Job Satisfaction. Harper and Brothers.

[12] James, A. O. and Ogbonna, I. G. (2013). Transformational vs. transactional leadership theories: Evidence in literature. International Review of Management and Business Research, 2(2), $355-361$.

[13] Madlock, P.E. (2008). The link between leadership style, communicator competence and employee satisfaction. Journal of Business Communication. 45 (1): $61-78$.

[14] Maloş, R. (2012). Leadership styles. Annals of EftimieMurgu University Resita, Fascicle II, Economic Studies. 421-426.

[15] Mester, C., Visser, D. and Roodt, G. (2003). Leadership style and its relation to employee attitudes and behavior. SA Journal of Industrial Psychology. 29 (2): $72-82$.

[16] Naidu, J., \& Van der Walt, M. S. (2005). An exploration of the relationship between leadership styles and the implementation of transformation interventions. SA Journal of Human Resource Management, 3(2), 1-10.

[17] Newstrom, J. W. and Davis, K. (1993). Organizational Behaviour: Human Behaviour at Work. McGraw Hill.

[18] Northouse, P. G. (2007). Leadership theory and practice. $4^{\text {th }}$ ed. Sage.

[19] Poon, J. M. (2003). Situational antecedents and outcomes of organizational politics perceptions. Journal of Managerial Psychology, 18(2), $138-155$. 
[20] Raveendran, T. and Gamage, A. S. (2018). Impact of leadership styles on employee performance: A review of literature. Journal of Business Studies, 5(2), $60-80$.

[21] Sauer, S.J. (2011). Taking the reins: the effects of new leader status and leadership style on team performance. Journal of Applied Psychology, 96(3), 574-587.

[22] Vroom, V. H. (1964). Work and Motivation. John Wiley and Sons.

[23] Vugt, M. V., Jepson, S. F., Hart, C. M. and Cremer, D. D. (2004). Autocratic leadership in social dilemmas: A threat to group stability. Journal of Experimental Social Psychology, 40(1), $1-13$. 